\title{
Synthesis of benzopolycyclic cage amines: NMDA receptor antagonist, trypanocidal and antiviral activities
}

\author{
Eva Torres ${ }^{\mathrm{a}}$, María D. Duque ${ }^{\mathrm{a}}$, Marta López-Querol ${ }^{\mathrm{b}}$, Martin C. Taylor ${ }^{\mathrm{c}}$, Lieve Naesens ${ }^{\mathrm{d}}$, Chunlong Ma ${ }^{\mathrm{e}}$, \\ Lawrence H. Pinto $^{\mathrm{e}}$, Francesc X. Sureda ${ }^{\mathrm{b}}$, John M. Kelly ${ }^{\mathrm{c}}$, Santiago Vázquez ${ }^{\mathrm{a}, *}$ \\ ${ }^{a}$ Laboratori de Química Farmacèutica (Unitat Associada al CSIC), Facultat de Farmàcia and Institute of Biomedicine (IBUB), Universitat de Barcelona, \\ Av. Diagonal, 643, Barcelona E-08028, Spain \\ ${ }^{\mathrm{b}}$ Unitat de Farmacologia, Facultat de Medicina i Ciències de la Salut, Universitat Rovira i Virgili, C./St. Llorenç 21, Reus E-43201, Spain \\ ${ }^{\mathrm{c}}$ London School of Hygiene and Tropical Medicine, Department of Infectious and Tropical Diseases, Keppel Street, London WC1E 7HT, United Kingdom \\ ${ }^{\mathrm{d}}$ Rega Institute for Medical Research, Katolieke Universiteit Leuven, 3000 Leuven, Belgium \\ ${ }^{\mathrm{e}}$ Department of Neurobiology and Physiology, Northwestern University, Evanston, IL 60208-3500, USA
}

\section{A R T I C L E I N F O}

\section{Article history:}

Received 6 August 2011

Revised 21 November 2011

Accepted 23 November 2011

Available online 2 December 2011

\section{Keywords:}

NMDA

Trypanosoma

Amantadine

Antivirals

Cage compounds

\begin{abstract}
A B S T R A C T
The synthesis of several 6,7,8,9,10,11-hexahydro-9-methyl-5,7:9,11-dimethano-5H-benzocyclononen-7amines is reported. Several of them display low micromolar NMDA receptor antagonist and/or trypanocidal activities. Two compounds are endowed with micromolar anti vesicular stomatitis virus activity, while only one compound shows micromolar anti-influenza activity. The anti-influenza activity of this compound does not seem to be mediated by blocking of the M2 protein.
\end{abstract}

(c) 2011 Elsevier Ltd. All rights reserved.

\section{Introduction}

Amantadine and its dimethyl derivative memantine, are two low-affinity, uncompetitive NMDAR antagonists, clinically used to treat Parkinson's and Alzheimer's diseases, respectively. ${ }^{1}$ Amantadine and its analogue rimantadine also target the M2 ion-channel protein of the influenza $A$ virus, having prophylactic and therapeutic activities in influenza A virus infections. However, many influenza virus strains have developed resistance to amantadine and rimantadine. ${ }^{2}$ Finally, amantadine, rimantadine and related polycyclic amines possess trypanocidal properties (Fig. 1). ${ }^{3}$

Considering the interesting pharmacological profile of amantadine, rimantadine and memantine, these compounds are ideal leads in the development of new agents to treat excitotoxic NMDAR channel mediated neurodegenerative diseases, influenza infections or African trypanosomiasis.

Recently, we started a research project directed to the synthesis and pharmacological evaluation of new analogs of amantadine, memantine and rimantadine. So far, we have synthesized ring-contracted analogs of these drugs and found that they showed NMDA receptor antagonism, many of them being more potent than

\footnotetext{
* Corresponding author. Tel.: +34 934024533; fax: +34 934035941.

E-mail address: svazquez@ub.edu (S. Vázquez).
}

amantadine but less potent than memantine. ${ }^{4}$ Moreover, several of these compounds displayed an anti-influenza activity very similar to that of amantadine. ${ }^{5}$ We also found that oxapolycyclic amines such as 3-alkyl(2-oxadamantyl)-1-amines and 1,2,3,5,6,7-hexahydro-1,5:3,7-dimethano-4-benzoxonin-3-amines of general structures $\mathbf{1}$ and 2, respectively, were also active as NMDA receptor antagonists. While these compounds lacked anti-influenza activity, several of them displayed trypanocidal activity (Fig. 2). ${ }^{6}$

Although several 1,2,3,5,6,7-hexahydro-1,5:3,7-dimethano-4benzoxonin-3-amines, 2, displayed low micromolar activity as NMDA receptor antagonists, the presence of an hemiaminal subunit in these compounds may raise serious concerns about their stability and thus of their further development as therapeutical agents. In fact, it is known that NGP1-01, a micromolar NMDA receptor antagonist containing an hemiaminal unit, ${ }^{7}$ decomposes easily in aqueous medium. ${ }^{8}$

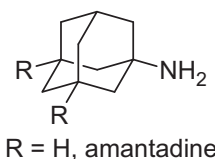

$\mathrm{R}=\mathrm{H}$, amantadine
$\mathrm{R}=\mathrm{Me}$, memantine

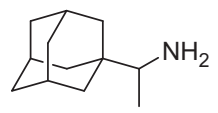

rimantadine

Fig. 1. Structures of amantadine, memantine and rimantadine. 


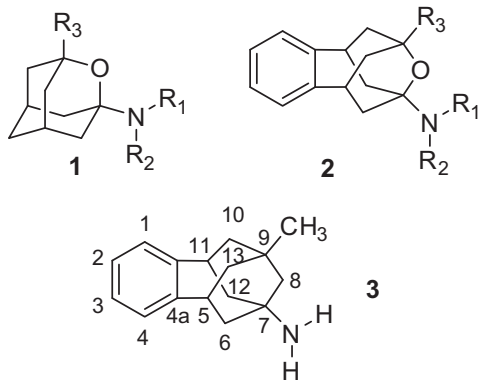

Fig. 2. General structures of previously studied polycycles $\mathbf{1}$ and $\mathbf{2}$ and the new amine 3.

In this Letter we wish to report the synthesis and pharmacological evaluation of several benzopolycyclic amines derived from 3 (Fig. 2). Several of these derivatives, that are devoid of the hemiaminal unit, show low micromolar NMDA receptor antagonist activity, although with higher $\mathrm{IC}_{50}$ than the previously described oxa-analogues. Interestingly, several of the new derivatives are endowed with low micromolar trypanocidal activity while only one compound has anti-influenza activity.

\section{Results and discussion}

\subsection{Synthesis}

Inspired by the work of Bishop et al., we prepared amine $\mathbf{3}$ from known diene $4 .^{9}$ Thus, Ritter-type transannular cyclization with chloroacetonitrile in acidic medium, ${ }^{10}$ and subsequent cleavage of the chloroacetyl group in the resulting chloroacetamide $\mathbf{5}$ with thiourea led to amine $\mathbf{3}$ in medium overall yield. ${ }^{11}$ Starting from amine $\mathbf{3}$ we have prepared several secondary and tertiary amines using classical methods in amine chemistry. Briefly, reductive alkylation of 3 with benzaldehyde and $\mathrm{NaBH}_{3} \mathrm{CN}$ led to 6 in $59 \%$ while reductive alkylation of $\mathbf{3}$ and $\mathbf{6}$ with formaldehyde and $\mathrm{NaBH}_{3} \mathrm{CN}$ furnished $\mathbf{7}$ and $\mathbf{1 1}$ in 55\% and 75\% yield, respectively. Hydrogenolysis of amine $\mathbf{7}$ led to secondary amine 8 in 74\% yield. Alternatively, 8 was obtained by reaction of $\mathbf{3}$ with methyl chloroformate followed by $\mathrm{LiAlH}_{4}$-mediated reduction of the intermediate carbamate, in $28 \%$ overall yield. Alkylation of $\mathbf{3}$ with propargyl bromide led to a mixture of $\mathbf{9}$ and $\mathbf{1 0}$ that were separated by column chromatography. Finally, alkylation of 3 with 1,5-dibromopentane gave the piperidine derivative $\mathbf{1 2}$ in 35\% yield (Scheme 1).

\subsection{NMDA receptor antagonist activity}

To evaluate if the synthesized compounds were able to antagonize NMDA receptors, we have measured its effect on the increase in intracellular calcium evoked by glutamate or NMDA (both $100 \mu \mathrm{M}$, in the presence of $10 \mu \mathrm{M}$ of glycine) on rat cultured cerebellar granule neurons. ${ }^{12}$ Inspection of the results shown in Table 1 reveals that piperidine derivative $\mathbf{1 2}$ had a value of $\mathrm{IC}_{50}$ (NMDA) very similar to that of amantadine, while compounds $3,8,9$ and 11 had values of $\mathrm{IC}_{50}$ (NMDA) that were in the micromolar order, lower than amantadine but higher than memantine (Table 1).

Benzyl derivatives $\mathbf{6}$ and $\mathbf{7}$ were devoid of activity, in agreement with our previous results with derivatives of general structures 1 and $2,{ }^{6}$ but in striking contrast with NGP1-01, a low micromolar

Table 1

$\mathrm{IC}_{50}(\mu \mathrm{M})$ values for $6,7,8,9,10,11$-hexahydro-5,7:9,11-dimethano-5 $H$-benzocyclononen-7-amines as NMDA antagonists ${ }^{\mathrm{a}, \mathrm{b}}$

\begin{tabular}{lcc}
\hline Compound & Glutamate $(100 \mu \mathrm{M})$ & NMDA $(100 \mu \mathrm{M})$ \\
\hline $\mathbf{3}$ & $22 \pm 3.9$ & $13.6 \pm 3.4$ \\
$\mathbf{8}$ & $455 \pm 216$ & $19.4 \pm 3.3$ \\
$\mathbf{9}$ & $>500$ & $27.5 \pm 13.2$ \\
$\mathbf{1 1}$ & $87 \pm 28$ & $11.8 \pm 3.1$ \\
$\mathbf{1 2}$ & $>500$ & $101 \pm 25$ \\
Amantadine & $358 \pm 130$ & $92 \pm 29$ \\
Memantine & $55 \pm 12$ & $1.5 \pm 0.1$ \\
\hline
\end{tabular}

a Functional data were obtained from primary cultures of cerebellar granule neurons using the method described in Section 4.2. by measuring the intracellular calcium concentration. Cells were challenged with glutamate (2nd column) or NMDA (3rd column) as indicated. Data shown are means \pm SEM of at least three separate experiments carried out on three different batches of cultured cells.

b Compounds $\mathbf{6}, \mathbf{7}$, and $\mathbf{1 0}$ were found to have low potency as glutamate IC $_{50}$ $>500 \mu \mathrm{M})$ and NMDA receptor antagonists $\left(\mathrm{IC}_{50}>200 \mu \mathrm{M}\right)$.

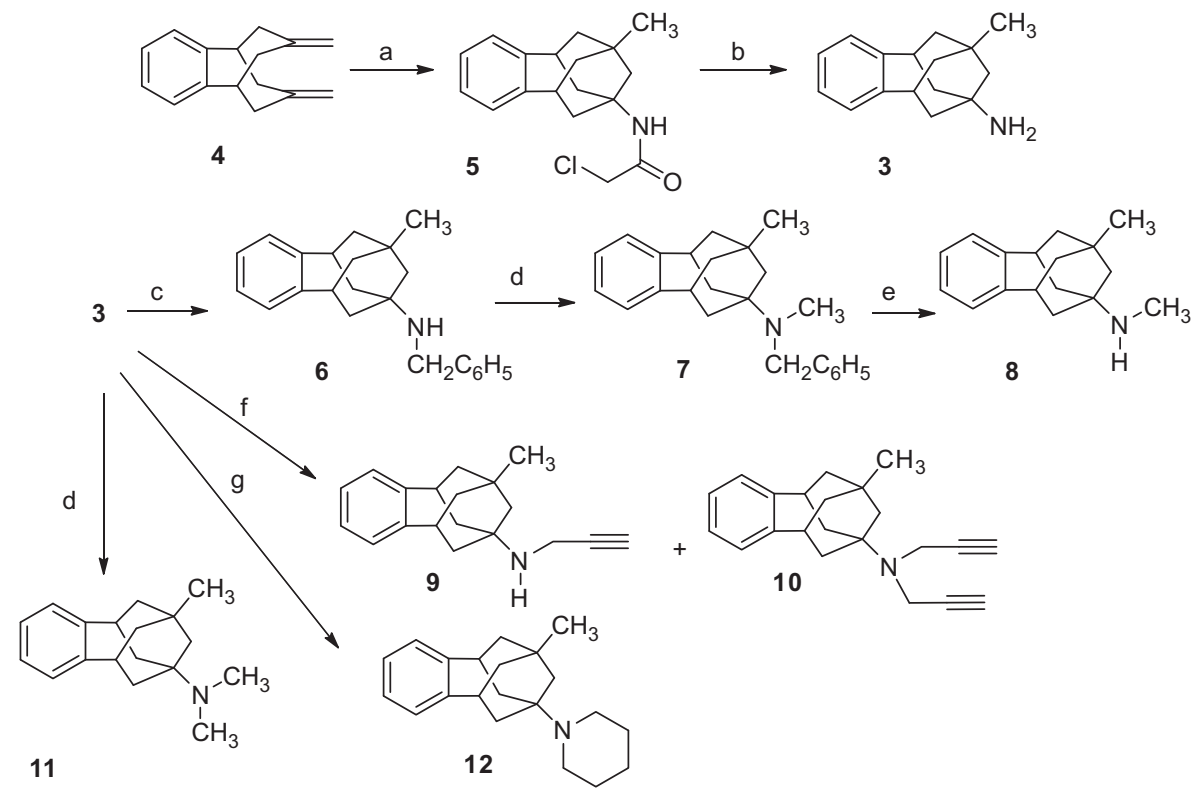

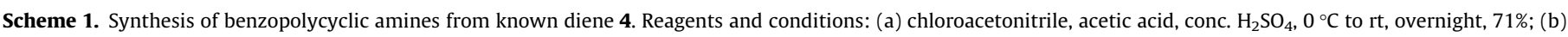

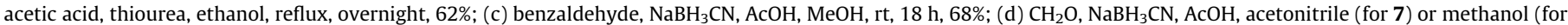

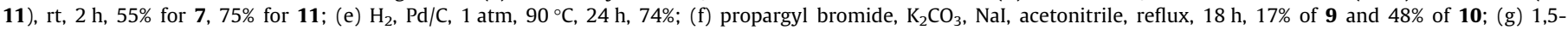
dibromopentane, $\mathrm{Et}_{3} \mathrm{~N}, \mathrm{DMF}, 60^{\circ} \mathrm{C}, 26 \mathrm{~h}, 35 \%$. 
NMDA receptor antagonist that features a benzyl group in its structure. $^{7}$

In our previous work with amines of general structure $\mathbf{2}$ we found that the NMDA receptor antagonist activity increased in going from the primary amine to the tertiary lower alkyl amine $\left(\mathrm{R}_{1}=\mathrm{R}_{2}=\mathrm{R}_{3}=\mathrm{H} ; \quad \mathrm{IC}_{50}=35 \mu \mathrm{M} ; \quad \mathrm{R}_{1}=\mathrm{R}_{3}=\mathrm{H}, \quad \mathrm{R}_{2}=\mathrm{CH}_{3} ; \quad I C_{50}=6 \mu \mathrm{M}\right.$; $\left.\mathrm{R}_{1}=\mathrm{R}_{2}=\mathrm{CH}_{3}, \mathrm{R}_{3}=\mathrm{H} ; \mathrm{IC}_{50}=6 \mu \mathrm{M}\right)$. However, the activity did not improved in going from $\mathbf{3}$ to $\mathbf{8}$ and $\mathbf{1 1}$.

We had previously found that the replacement of the methylene unit of C-2 in amantadine by an oxygen atom, as in compound $\mathbf{1}$ $\left(R_{1}=R_{2}=R_{3}=H\right)$, led to less potent NMDA receptor antagonists. ${ }^{6 a}$ Taking into account the good activity of several of our oxapolycyclic amines of general structure $\mathbf{2}$, we expected that the replacement of the oxygen atom on these derivatives by a methylene unit, as in the newer derivatives herein reported, would lead to more potent NMDA receptor antagonists. In fact, amine $3\left(\mathrm{IC}_{50}=13.6 \mu \mathrm{M}\right)$ is much more potent than the previously described amine 2 $\left(\mathrm{R}_{1}=\mathrm{R}_{2}=\mathrm{H}, \mathrm{R}_{3}=\mathrm{CH}_{3} ; \mathrm{IC}_{50}=98 \mu \mathrm{M}\right)$. However, this trend is not general, and, for example, amine $\mathbf{1 1}$ is 3 times less potent $\left(\mathrm{IC}_{50}=12 \mu \mathrm{M}\right)$ than tertiary amine $\mathbf{2}\left(\mathrm{R}_{1}=\mathrm{R}_{2}=\mathrm{R}_{3}=\mathrm{CH}_{3} ; \mathrm{IC}_{50}=4 \mu \mathrm{M}\right)$.

Worthy of note, the $\mathrm{IC}_{50}$ of compound $\mathbf{8}$ as NMDA receptor antagonist is more than 20 times lower than its $\mathrm{IC}_{50}$ as glutamate receptor antagonist, in a similar manner than has been found for memantine.

\subsection{Trypanocidal activity}

Human African trypanosomiasis (HAT) is caused by infection with protozoan parasites of the Trypanosoma brucei species complex. The disease is endemic in many parts of sub-Saharan Africa,

Table 2

$\mathrm{IC}_{50}$ and $\mathrm{IC}_{90}(\mu \mathrm{M})$ values for oxapolycyclic cage amines that display inhibitory activity against cultured bloodstream form T. bruce $^{\mathrm{a}}$

\begin{tabular}{lrr}
\hline Compound & $\mathrm{IC}_{50}(\mu \mathrm{M})$ & \multicolumn{1}{c}{$\mathrm{IC}_{90}(\mu \mathrm{M})$} \\
\hline $\mathbf{3}$ & $4.80 \pm 0.41$ & $9.60 \pm 0.30$ \\
$\mathbf{6}$ & $3.00 \pm 0.32$ & $6.55 \pm 0.32$ \\
$\mathbf{7}$ & $5.25 \pm 0.99$ & $10.85 \pm 0.59$ \\
$\mathbf{8}$ & $4.46 \pm 0.54$ & $6.66 \pm 0.18$ \\
$\mathbf{9}$ & $1.99 \pm 0.46$ & $3.14 \pm 0.10$ \\
$\mathbf{1 0}$ & $13.44 \pm 0.56$ & $21.61 \pm 0.44$ \\
Rimantadine & $7.04 \pm 0.27$ & $13.97 \pm 1.68$ \\
Memantine & $13.75 \pm 1.26$ & $21.43 \pm 0.55$ \\
\hline
\end{tabular}

${ }^{\text {a }}$ Compounds were tested for in vitro activity against bloodstream form T. brucei at a range of concentrations and $\mathrm{IC}_{50}$ and $\mathrm{IC}_{90}$ values established (Section 4.5). Data are the mean of triplicate experiments \pm SEM. Values for rimantadine and memantine are shown for comparison. with upwards of 60 million people at risk. A process of antigenic variation prevents elimination of the parasite by the immune system, and the prospects of developing a vaccine are thought to be remote. New drugs against HAT are therefore a major priority. Drugs currently available against HAT are characterized by problems including toxicity, limited efficacy, cost and the need to administer under medical supervision.

The anti-influenza virus drug rimantadine has been shown to be active in vitro against bloodstream form $T$. brucei and other adamantane derivatives have even greater activity. 3,4,13 Moreover, very recently, we found that several derivatives of general structures $\mathbf{1}$ and $\mathbf{2}$ showed significant activity against bloodstream form T. brucei. ${ }^{6}$ We therefore investigated if the newly synthesized polycyclic cage amines reported here also displayed significant activity against this parasite.

A total of 7 compounds were tested. Of these, $\mathbf{1 1}$ displayed little or no inhibitory activity against cultured bloodstream form $T$. brucei at $5 \mu \mathrm{g} \mathrm{mL}^{-1}(15-20 \mu \mathrm{M})$. However, compound 10 inhibited parasite growth, at a level comparable to memantine. More interestingly, compounds 3, 6, 7, 8 and 9 significantly inhibited parasite growth, at levels lower than rimantadine and memantine (Table 2 ). The $\mathrm{IC}_{90}$ of the more active compound, $\mathbf{9}$, was more than 4 times lower than that of rimantadine. Inspection of the results shown in Table 2 reveals that secondary amines 6,8 and 9 were more potent than tertiary amines 7, 10 and $\mathbf{1 1}$.

\subsection{Antiviral activity}

None of the synthesized compounds was found to have antiviral activity against the enveloped DNA viruses herpes simplex virus (type 1 or type 2 ) or vaccinia virus; the enveloped RNA viruses feline coronavirus, parainfluenza-3 virus, respiratory syncytial virus, sindbis virus or Punta Toro virus; or the non-enveloped RNA viruses Coxsackievirus B4 and Reovirus-1.

Compound $\mathbf{1 0}$ was active against vesicular stomatitis virus (VSV) in HeLa cells, with an $\mathrm{EC}_{50}$ (50\% antiviral effective concentration) of $4 \mu \mathrm{M}$ and a selectivity index (ratio of cytotoxic to antiviral concentration) of 25 . Another compound, 12, was only weakly active $\left(\mathrm{EC}_{50}=54 \mu \mathrm{M}\right)$. The antiviral data obtained by microscopy were confirmed by a colorimetric cell viability assay. However, both compounds were not active against VSV in HEL cells, which suggest that the anti-VSV activity may be cell type-dependent.

In the influenza virus assays, all compounds proved to be inactive against the A/H3N2 subtype and influenza B virus. Interestingly, benzyl derivative 6 displayed reasonable activity against the influenza $\mathrm{A} / \mathrm{H} 1 \mathrm{~N} 1$ subtype (antiviral $\mathrm{EC}_{50}=10 \mu \mathrm{M}$ ).

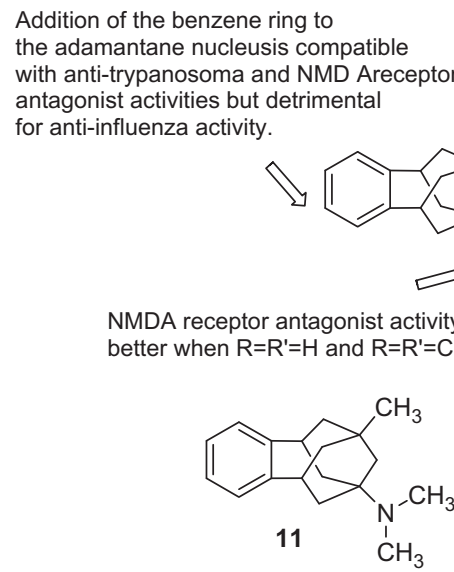

Introduction of this methylene unit instead of the oxygen atom previously studied $R$ improves the anti-trypanosoma activity.

A benzyl substituent is compatible with anti-trypanosoma activity but detrimental for NMDA antagonism.

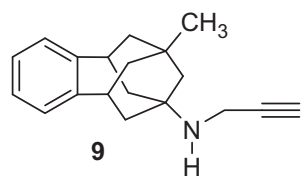

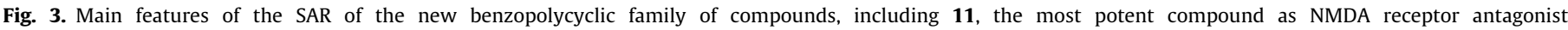
$\left(\mathrm{IC}_{50}=11.8 \pm 3.1 \mu \mathrm{M}\right)$, and $\mathbf{9}$, the most potent compound as trypanocidal $\left(\mathrm{IC}_{50}=1.99 \pm 0.46 \mu \mathrm{M} ; \mathrm{IC}_{90}=3.14 \pm 0.10 \mu \mathrm{M}\right)$. 
It is well-known that the target of amantadine and rimantadine is the influenza A virus M2 channel protein and that a single S31N mutation in $\mathrm{M} 2$ renders the virus resistant to both drugs. ${ }^{2,14}$ As most of the currently circulating subtypes of influenza A virus, A/H3N2 and $\mathrm{A} / \mathrm{H} 1 \mathrm{~N} 1$, carry the $\mathrm{S} 31 \mathrm{~N}$ mutation in $\mathrm{M} 2$, there is an urgent need for the development of novel anti-influenza drugs that are effective against the most common amantadine-resistant mutants. ${ }^{15}$

The influenza A/PuertoRico/8/34 strain used for testing the activity of amine 6 has an M2 channel carrying two substituions associated with amantadine resistance, that is $\mathrm{S} 31 \mathrm{~N}$ and V27T. In order to assess if the target of $\mathbf{6}$ was the M2 protein, the inhibitory activity of 6 was tested on A/M2 channels expressed in Xenopus oocytes using the two-electrode voltage clamps (TEV) technique. Amine 6, at $100 \mu \mathrm{M}$, was unable to inhibit the activity of the wild-type (amantadine-sensitive) and the S31N and the V27A (amantadine-resistant) mutants, thus suggesting that $\mathbf{6}$ interacts with a different target in the virus. Neither $\mathbf{3}$ nor $\mathbf{1 1}$ were able to inhibit the activity of the wild-type and the S31N and the V27A mutants.

\section{Conclusions}

In summary, we have synthesized and fully characterized several benzopolycyclic amines. Several of the derivatives were more potent than amantadine against NMDA-induced calcium increase in cerebellar granule neurons, although they were less potent than memantine. Several amines displayed a significant level of trypanocidal activity, being up to four times more potent than rimantadine. Figure 3 summarizes the main features of the SAR of these new compounds, including the most potent compounds.

Regarding antiviral activity, compound $\mathbf{1 0}$ displayed anti-VSV activity in HeLa cells, but not in HEL cells, suggesting that its antiviral activity can be cell type-dependent. Finally, benzyl derivative 6, that is not active as NMDA receptor antagonist, is a low micromolar inhibitor of the influenza $\mathrm{A} / \mathrm{H} 1 \mathrm{~N} 1$ subtype. Interestingly, this anti-viral activity is not mediated by M2 channel blocking.

The synthesis and pharmacological evaluation of more polycyclic cage amines are in progress.

\section{Experimental}

\subsection{Chemistry}

\subsubsection{General}

Melting points were determined in open capillary tubes. Unless otherwise stated, NMR spectra were recorded in $\mathrm{CD}_{3} \mathrm{OD}$ in the following spectrometers: ${ }^{1} \mathrm{H}$ NMR $(500 \mathrm{MHz}),{ }^{13} \mathrm{C}$ NMR $(100.6 \mathrm{MHz})$. Chemical shits $(\delta)$ are reported in ppm related to internal tetramethylsilane (TMS). Assignments given for the NMR spectra are based on DEPT, COSY ${ }^{1} \mathrm{H} /{ }^{1} \mathrm{H}$, HETCOR ${ }^{1} \mathrm{H} /{ }^{13} \mathrm{C}$ (HSQC and HMBC sequences for one bond and long range ${ }^{1} \mathrm{H} /{ }^{13} \mathrm{C}$ heterocorrelations, respectively) and NOESY experiments for selected compounds. For the MS and GC/MS analyses the sample was introduced directly or through a gas chromatograph. For GC/MS analyses a 30-meter column [5\% diphenyl-95\% dimethylpolysiloxane, conditions: $10 \mathrm{psi}$, initial temperature: $35^{\circ} \mathrm{C}(2 \mathrm{~min})$, then heating at a range of $8{ }^{\circ} \mathrm{C} / \mathrm{min}$ till $300^{\circ} \mathrm{C}$, then isothermic at $300^{\circ} \mathrm{C}$ ] was used. The electron impact $(70 \mathrm{eV})$ or chemical ionization $\left(\mathrm{CH}_{4}\right)$ techniques were used. Only significant ions are given: those with higher relative ratio, except for the ions with higher $m / z$ values. Accurate mass measurements were obtained using ESI technic. Absorption values in the IR spectra ( $\mathrm{KBr})$ are given as wave-numbers $\left(\mathrm{cm}^{-1}\right)$. Only the more intense bands are given. Column chromatography was performed on silica gel $60 \AA$ (35-70 mesh). For the thin layer chromatography (TLC) aluminum-backed sheets with silica gel 60 $\mathrm{F}_{254}$ were used and spots were visualized with UV light and/or $1 \%$ aqueous solution of $\mathrm{KMnO}_{4}$.
4.1.2. $N$-(6,7,8,9,10,11-Hexahydro-9-methyl-5,7:9,11-dimethano -5H-benzocyclononen-7-yl)chloroacetamide, 5

A suspension of diene $4(5.3 \mathrm{~g}, 25.2 \mathrm{mmol})$, chloroacetonitrile $(6.5 \mathrm{~mL})$ and acetic acid $(17 \mathrm{~mL})$ was cooled to $0{ }^{\circ} \mathrm{C}$ and concentrated $\mathrm{H}_{2} \mathrm{SO}_{4} \quad(8.2 \mathrm{~mL}, 151.2 \mathrm{mmol})$ was added dropwise $\left(T<10^{\circ} \mathrm{C}\right)$. The mixture was allowed to reach room temperature and was stirred overnight. The suspension was added to ice $(120 \mathrm{~g})$ and a yellow solid precipitated. The precipitate was filtered and solved in dichloromethane $(100 \mathrm{~mL})$. The organic phase was dried with anhyd $\mathrm{Na}_{2} \mathrm{SO}_{4}$, filtered and concentrated in vacuo to give 5 as a yellow solid ( $5.44 \mathrm{~g}, 71 \%$ yield). The analytical sample of 5 was obtained by crystallization from $\mathrm{CH}_{2} \mathrm{Cl}_{2}$, mp $166-168^{\circ} \mathrm{C}$. IR 3320 , 3301, 3062, 2949, 2910, 2861, 1659, 1651, 1540, 1492, 1451, $1431,1361,1328,1312,1210,1145,1091,1009,971,943,765$, 747, 694, 651, 610, 507, $478 \mathrm{~cm}^{-1} .{ }^{1} \mathrm{H}$ NMR $\left(\mathrm{CDCl}_{3}\right) 0.94(\mathrm{~s}, 3 \mathrm{H}$, $\left.\mathrm{CH}_{3}\right), 1.56$ [d, $J=13.5 \mathrm{~Hz}, 2 \mathrm{H}, 10(13)-\mathrm{H}_{\mathrm{b}}$ ], 1.67 [ddd, $J=13.5 \mathrm{~Hz}$, $\left.J^{\prime}=6.0 \mathrm{~Hz}, J^{\prime \prime}=2.0 \mathrm{~Hz}, 2 \mathrm{H}, 10(13)-\mathrm{H}_{\mathrm{a}}\right], 1.85\left(\mathrm{~s}, 2 \mathrm{H}, 8-\mathrm{H}_{2}\right), 2.09$ [d, $J=13 \mathrm{~Hz}, 2 \mathrm{H}, 6(12)-\mathrm{H}_{\mathrm{b}}$ ], 2.17 [ddd, $J=13 \mathrm{~Hz}, J^{\prime}=6.0 \mathrm{~Hz}, J^{\prime \prime}=2.0 \mathrm{~Hz}$, $2 \mathrm{H}, 6(12)-\mathrm{H}_{\mathrm{a}}$ ], $3.09\left(\mathrm{tt}, J=6.0 \mathrm{~Hz}, J^{\prime}=2.0 \mathrm{~Hz}, 2 \mathrm{H}, 5(11)-\mathrm{H}\right], 3.93(\mathrm{~s}$, $2 \mathrm{H}, \mathrm{CH}_{2} \mathrm{Cl}$ ), 6.31 (br s, $1 \mathrm{H}, \mathrm{NH}$ ), 7.04-7.10 [complex signal, $4 \mathrm{H}$, 1(4)-H and 2(3)-H]. ${ }^{13} \mathrm{C}$ NMR $\left(\mathrm{CDCl}_{3}\right) 32.1\left(\mathrm{CH}_{3}, \mathrm{C} 9-\mathrm{CH}_{3}\right), 33.6(\mathrm{C}$, C9), $38.7\left[\mathrm{CH}_{2}, \mathrm{C} 6(12)\right], 40.9[\mathrm{CH}, \mathrm{C} 5(11)], 41.0\left[\mathrm{CH}_{2}, \mathrm{C} 10(13)\right]$, $42.9\left(\mathrm{CH}_{2}, \mathrm{CH}_{2} \mathrm{Cl}\right), 46.9\left(\mathrm{CH}_{2}, \mathrm{C} 8\right), 54.9(\mathrm{C}, \mathrm{C} 7), 126.4[\mathrm{CH}, \mathrm{C} 2(3)]$, 128.0 [CH, C1(4)], 146.0 [C, C4a(C11a)], 164.5 (C, CO). MS (EI), m/z (\%): $303\left(\mathrm{M}^{+}, 31\right), 268(18), 211\left[\left(\mathrm{C}_{16} \mathrm{H}_{19}\right)^{+}, 29\right], 210$ (100), 195 (28), 182 (13), 181 (15), 167 (11), 156 (15), 155 (82), 154 (20), 143 (14), 142 (13), 141 (20), 129 (19), 128 (23), 115 (17). Anal. Calcd. for $\mathrm{C}_{18} \mathrm{H}_{22} \mathrm{ClNO}$ (303.83): $\mathrm{C} 71.16, \mathrm{H} 7.30, \mathrm{~N} 4.61, \mathrm{Cl} 11.67$. Found C 71.07, H 7.28, N 4.50, Cl 11.44.

\subsubsection{6,7,8,9,10,11-Hexahydro-9-methyl-5,7:9,11-dimethano-5H -benzocyclononen-7-amine hydrochloride, $3 \cdot \mathbf{H C l}$}

A mixture of chloroacetamide $\mathbf{5}(7.21 \mathrm{~g}, 23.7 \mathrm{mml})$, thiourea $(2.16 \mathrm{~g}, 28.44 \mathrm{mmol})$, acetic acid $(8.7 \mathrm{~mL})$ in ethanol $(44 \mathrm{~mL})$ was stirred under reflux for $18 \mathrm{~h}$. To the cold solution water $(250 \mathrm{~mL})$, and $10 \mathrm{~N} \mathrm{NaOH}(80 \mathrm{~mL})$ were added. The base aqueous solution was extracted with EtOAc $(3 \times 300 \mathrm{~mL})$. The combined organic extracts were dried with anhyd $\mathrm{Na}_{2} \mathrm{SO}_{4}$, filtered and concentrated in vacuo to give a brown oily residue $(7.19 \mathrm{~g})$. The residue was taken in EtOAc and the amine $\mathbf{3}$ was precipitated as its hydrochloride by adding an excess of $\mathrm{Et}_{2} \mathrm{O} \cdot \mathrm{HCl}(3.87 \mathrm{~g}, 62 \%$ yield). The analytical sample was obtained by crystallization from 2-propanol, $\mathrm{mp}$ $287-288^{\circ} \mathrm{C}$. IR 3499, 2985, 2944, 2907, 2860, 2717, 2680, 2622, 2581, 2548, 2061, 1606, 1509, 1495, 1454, 1362, 757, 578, $471 \mathrm{~cm}^{-1} .{ }^{1} \mathrm{H}$ NMR $0.87\left(\mathrm{~s}, 3 \mathrm{H}, \mathrm{CH}_{3}\right), 1.38[\mathrm{~d}, J=13.5 \mathrm{~Hz}, 2 \mathrm{H}$, $10(13)-\mathrm{H}_{\mathrm{b}}$ ] 1.54 [dd, $J=13.5 \mathrm{~Hz}, J^{\prime}=6.0 \mathrm{~Hz}, 2 \mathrm{H}, 10(13)-\mathrm{H}_{\mathrm{a}}$ ], 1.58 $\left(\mathrm{s}, 2 \mathrm{H}, 8-\mathrm{H}_{2}\right), 1.73\left[\mathrm{~d}, J=13.0 \mathrm{~Hz}, 2 \mathrm{H}, 6(12)-\mathrm{H}_{\mathrm{b}}\right], 1.96$ [dd, $\left.J=13.0 \mathrm{~Hz}, J^{\prime}=6.0 \mathrm{~Hz}, 2 \mathrm{H}, 6(12)-\mathrm{H}_{\mathrm{a}}\right], 3.09[\mathrm{t}, J=6.0 \mathrm{~Hz}, 2 \mathrm{H}, 5(11)-$ $\mathrm{H}$ ], 7.05 (s, 4H, Ar-H), 8.31 (br s, 3H, NH3). ${ }^{13} \mathrm{C}$ NMR $32.3\left(\mathrm{CH}_{3}\right.$, $\left.\mathrm{C} 9-\mathrm{CH}_{3}\right), 34.7$ (C, C9), $39.3\left[\mathrm{CH}_{2}, \mathrm{C} 6(12)\right], 41.6\left[\mathrm{CH}_{2}, \mathrm{C} 10(13)\right]$, 41.7 [CH, C5(11)], $47.2\left(\mathrm{CH}_{2}, \mathrm{C} 8\right), 55.5(\mathrm{C}, \mathrm{C} 7), 128.0[\mathrm{CH}, \mathrm{C} 2(3)]$, $129.2[\mathrm{CH}, \mathrm{C} 1(4)], 146.4$ [C, C4a(C11a)]. MS (EI), m/z (\%): 227 ( $\left.\mathrm{M}^{+}, 100\right), 212$ (28), 185 (65), 171 (12), 170 (52), 157 (15), 156 (58), 155 (32), 153 (11), 144 (21), 143 (15), 141 (17), 130 (12), 129 (18), 128 (25), 115 (22), 108 (22), 94 (27). HRMS-ESI+ m/z $[\mathrm{M}+\mathrm{H}]^{+}$calcd for $\mathrm{C}_{16} \mathrm{H}_{22} \mathrm{~N}+\mathrm{H}$ : 228.1746, found: 228.1743 .

\subsection{4. $N$-Benzyl-6,7,8,9,10,11-hexahydro-9-methyl-5,7:9,11-dime thano-5H-benzocyclononen-7-amine hydrochloride, $6 \cdot \mathbf{H C l}$}

To a solution of amine $\mathbf{3 . H C l}(200 \mathrm{mg}, 0.76 \mathrm{mmol})$ in $\mathrm{MeOH}$ $(10 \mathrm{~mL}), \mathrm{NaBH}_{3} \mathrm{CN}(104 \mathrm{mg}, 1.65 \mathrm{mmol}), \mathrm{AcOH}(0.25 \mathrm{~mL})$ and benzaldehyde $(80.4 \mathrm{mg}, 0.76 \mathrm{mmol})$ were added and the mixture was stirred at room temperature for $18 \mathrm{~h}$ and concentrated in vacuo to dryness. Water $(10 \mathrm{~mL})$ was added to the residue, and the mixture was extracted with $\mathrm{Et}_{2} \mathrm{O}(4 \times 15 \mathrm{~mL})$. The combined organic extracts were washed with $2 \mathrm{~N} \mathrm{NaOH}(3 \times 25 \mathrm{~mL})$, brine 
$(2 \times 25 \mathrm{~mL})$, dried with anhyd $\mathrm{Na}_{2} \mathrm{SO}_{4}$, filtered and concentrated in vacuo. The residue was taken in EtOAc and the amine 6 was precipitated as its hydrochloride ( $159 \mathrm{mg}, 68 \%$ yield) by adding an excess of $\mathrm{Et}_{2} \mathrm{O} \cdot \mathrm{HCl}$. The analytical sample was obtained by crystallization from methanol $/ \mathrm{Et}_{2} \mathrm{O}, \mathrm{mp} 263-264{ }^{\circ} \mathrm{C}$. IR 3410, 2948, 2912, 2840, 2733, 2407, 1494, 1455, 1364, 1347, 1307, 1217, 1127, 992, 943, 755, 696, 567, $501 \mathrm{~cm}^{-1} .{ }^{1} \mathrm{H}$ NMR $\left(\mathrm{CDCl}_{3}\right) 0.89\left(\mathrm{~s}, 3 \mathrm{H}, \mathrm{CH}_{3}\right), 1.50$ $\left[\mathrm{d}, J=13.5 \mathrm{~Hz}, 2 \mathrm{H}, 10(13)-\mathrm{H}_{\mathrm{b}}\right], 1.66\left[\mathrm{dd}, J=13.5 \mathrm{~Hz}, J^{\prime}=6.0 \mathrm{~Hz}, 2 \mathrm{H}\right.$, $10(13)-\mathrm{H}_{\mathrm{a}}$ ], 1.92 [d, $J=12.5 \mathrm{~Hz}, 2 \mathrm{H}, 6(12)-\mathrm{H}_{\mathrm{b}}$ ], $2.00\left(\mathrm{~s}, 2 \mathrm{H}, 8-\mathrm{H}_{2}\right)$, 2.24 [dd, $J=12.5 \mathrm{~Hz}, J^{\prime}=6.0 \mathrm{~Hz}, 2 \mathrm{H}, 6(12)-\mathrm{H}_{\mathrm{a}}$ ], 3.08 [m, 2H, 5(11)$\mathrm{H}$ ], 3.80 (br s, $2 \mathrm{H}, \mathrm{CH}_{2} \mathrm{C}_{6} \mathrm{H}_{5}$ ), $7.00[\mathrm{~m}, 2 \mathrm{H}, 1(4)-\mathrm{Ar}-\mathrm{H}], 7.08[\mathrm{~m}, 2 \mathrm{H}$, 2(3)-Ar-H], 7.20 (t, $\left.J=7.5 \mathrm{~Hz}, 1, \operatorname{Ar}-\mathrm{H}_{\text {para }}\right), 7.27$ (t, $J=7.5 \mathrm{~Hz}, 2 \mathrm{H}$, Ar- $\mathrm{H}_{\text {meta }}$ ), 7.61 (d, J = 7.5 Hz, 2H, Ar-H ${ }^{13} \mathrm{C}$ NMR $32.3\left(\mathrm{CH}_{3}, \mathrm{C} 9-\mathrm{CH}_{3}\right), 35.0(\mathrm{C}, \mathrm{C} 9), 37.0\left[\mathrm{CH}_{2}, \mathrm{C} 6(12)\right], 41.7$ [CH, C5(11)], $41.8\left[\mathrm{CH}_{2}, \mathrm{C} 10(13)\right], 45.0\left(\mathrm{CH}_{2}, \mathrm{CH}_{2} \mathrm{C}_{6} \mathrm{H}_{5}\right), 45.4\left(\mathrm{CH}_{2}\right.$, C8), 62.0 (C, C7), 128.0 [CH, C2(3)], 129.2 [CH, C1(4)], 130.3 ( $\mathrm{CH}$, Ar- $\left.\mathrm{C}_{\text {meta }}\right), 130.5\left(\mathrm{CH}, \mathrm{Ar}-\mathrm{C}_{\text {para }}\right), 131.2\left(\mathrm{CH}, \mathrm{Ar}-\mathrm{C}_{\text {ortho }}\right), 133.1$ (C, Ar$\left.\mathrm{C}_{\text {ipso }}\right), 146.4$ [C, C4a(C11a)]. MS (EI), $m / z(\%): 317\left(\mathrm{M}^{+}, 100\right), 302$ (23), 276 (15), 275 (64), 260 (19), 246 (23), 211 [( $\left.\left.\mathrm{C}_{16} \mathrm{H}_{19}\right)^{+}, 17\right]$, 184 (21), 169 (11), 155 (28), 147 (16), 146 (14), 143 (18), 141 (18), 129 (18), 128 (19), 115 (15), 91 (82). HRMS-ESI+ m/z $[\mathrm{M}+\mathrm{H}]^{+}$calcd for $\mathrm{C}_{23} \mathrm{H}_{28} \mathrm{~N}+\mathrm{H}$ : 318.2216, found: 318.2215. Anal. Calcd. for $\mathrm{C}_{23} \mathrm{H}_{27} \mathrm{~N} \cdot 1.1 \mathrm{HCl} \cdot 0.3 \mathrm{H}_{2} \mathrm{O}$ (362.99): $\mathrm{C} 76.11, \mathrm{H} 7.97, \mathrm{~N}$ 3.86, $\mathrm{Cl}$ 10.74. Found $\mathrm{C}$ 76.42, $\mathrm{H}$ 7.65, N 3.62, Cl 10.36.

\subsection{5. $N$-Benzyl- $N$-methyl-6,7,8,9,10,11-hexahydro-9-methyl-5, 7:9,11-dimethano-5H-benzocyclononen-7-amine hydrochloride, $7 \cdot \mathbf{H C l}$}

To a solution of $\mathbf{6} \cdot \mathbf{H C l}(327 \mathrm{mg}, 0.96 \mathrm{mmol})$ in acetonitrile $(10 \mathrm{~mL})$, formaldehyde $(0.75 \mathrm{~mL}, 37 \%$ wt. in water solution, $9.60 \mathrm{mmol}$ ) and $\mathrm{NaBH}_{3} \mathrm{CN}(180 \mathrm{mg}, 2.88 \mathrm{mmol}$ ) were added. The mixture was stirred for $30 \mathrm{~min}$ at room temperature, acetic acid $(0.5 \mathrm{~mL})$ was added and the mixture was stirred at room temperature for $2 \mathrm{~h}$. An additional portion of $\mathrm{NaBH}_{3} \mathrm{CN}(180 \mathrm{mg}, 2.88 \mathrm{mmol})$ was added and the mixture was further stirred at room temperature for $2 \mathrm{~h}$. The mixture was concentrated to dryness, $2 \mathrm{~N} \mathrm{NaOH}(10 \mathrm{~mL})$ was added and the suspension was extracted with $\mathrm{CH}_{2} \mathrm{Cl}_{2}$ $(3 \times 15 \mathrm{~mL})$. The combined organic phases were washed with $\mathrm{H}_{2} \mathrm{O}$ $(2 \times 10 \mathrm{~mL})$, dried with anhyd $\mathrm{Na}_{2} \mathrm{SO}_{4}$, filtered and concentrated in vacuo to give 7 as an oil. Its hydrochloride was obtained by adding an excess of $\mathrm{Et}_{2} \mathrm{O} \cdot \mathrm{HCl}$ to a solution of the amine in EtOAc, followed by filtration of the white solid precipitate ( $194 \mathrm{mg}$, 55\% yield). The analytical sample was obtained by crystallization from methanol/

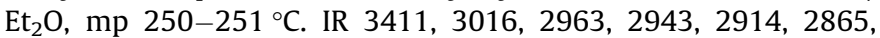
2844, 2461, 2375, 1492, 1452, 1421, 1384, 1308, 1277, 1264, $1214,1177,1156,1121,1101,1052,1005,973,950,892,869,756$, 746, 698, 573, $515 \mathrm{~cm}^{-1} .{ }^{1} \mathrm{H}$ NMR $\left(\mathrm{CDCl}_{3}\right) 1.00\left(\mathrm{~s}, 3 \mathrm{H}, \mathrm{CH}_{3}\right), 1.59$ [d, $\left.J=13.5 \mathrm{~Hz}, 2 \mathrm{H}, 10(13)-\mathrm{H}_{\mathrm{b}}\right], 1.73\left[\mathrm{ddm}, J=13.5 \mathrm{~Hz}, J^{\prime}=6.0 \mathrm{~Hz}\right.$, $2 \mathrm{H}, 10(13)-\mathrm{H}_{\mathrm{a}} \mathrm{]}, 2.01\left(\mathrm{~d}, \mathrm{~J}=12 \mathrm{~Hz}, 1 \mathrm{H}, 6-\mathrm{H}_{\mathrm{b}}\right.$ or $\left.12-\mathrm{H}_{\mathrm{b}}\right), 2.06$ (complex signal, $2 \mathrm{H}, 8-\mathrm{H}_{\mathrm{a}}$ and $12-\mathrm{H}_{\mathrm{b}}$ or $\left.6-\mathrm{H}_{\mathrm{b}}\right), 2.25\left(\mathrm{~d}, J=12.0 \mathrm{~Hz}, 1 \mathrm{H}, 8-\mathrm{H}_{\mathrm{b}}\right)$, $2.38\left(\mathrm{~d}, J=5.0 \mathrm{~Hz}, 3 \mathrm{H}, \mathrm{N}-\mathrm{CH}_{3}\right), 2.55(\mathrm{~m}, 1 \mathrm{H})$ and $2.65(\mathrm{~m}, 1 \mathrm{H})(6-$ $\mathrm{H}_{\mathrm{a}}$ and $\left.12-\mathrm{H}_{\mathrm{a}}\right), 3.25(\mathrm{t}, J=6.0 \mathrm{~Hz}, 1 \mathrm{H})$ and $3.27(\mathrm{t}, J=6.0 \mathrm{~Hz}, 1 \mathrm{H})$ $\left(5 \mathrm{H}\right.$ and $11-\mathrm{H}$ ), 3.65 (dd, $J=12.5 \mathrm{~Hz}, J^{\prime}=9.0 \mathrm{~Hz}, 1 \mathrm{H}, \mathrm{CH}_{2}-\mathrm{C}_{6} \mathrm{H}_{5}$ ), $4.66\left(\mathrm{dd}, J=12.5 \mathrm{~Hz}, J^{\prime}=3.5 \mathrm{~Hz}, 1 \mathrm{H}, \mathrm{CH}_{2}-\mathrm{C}_{6} \mathrm{H}_{5}\right), 7.06$ [m, 2H, 1(4)Ar-H], 7.11 [m, 2H, 2(3)-Ar-H], 7.33-7.39 (complex signal, 3H, Ar$\mathrm{H}_{\text {meta }}$ and $\left.\mathrm{Ar}_{\text {para }}\right), 7.69$ (dd, $\left.J=7.5 \mathrm{~Hz}, J=2.0 \mathrm{~Hz}, 2 \mathrm{H}, \mathrm{Ar}-\mathrm{H}_{\text {ortho }}\right), 11.9$ (br s, $\left.2 \mathrm{H}, \mathrm{NH}_{2}\right) .{ }^{13} \mathrm{C} \mathrm{NMR}\left(\mathrm{CDCl}_{3}\right) 31.7\left(\mathrm{CH}_{3}, \mathrm{CH}_{3}-\mathrm{N}\right), 31.9\left(\mathrm{CH}_{3}, \mathrm{C} 9-\right.$ $\left.\mathrm{CH}_{3}\right), 33.1\left(\mathrm{CH}_{2}\right)$ and $33.5\left(\mathrm{CH}_{2}\right)(\mathrm{C} 6$ and $\mathrm{C} 12), 34.5$ (C, $\left.\mathrm{C} 9\right), 40.1$ $\left(\mathrm{CH}_{2}\right)$, and $40.28\left(\mathrm{CH}_{2}\right)(\mathrm{C} 10$ and $\mathrm{C} 13), 40.31[\mathrm{CH}, \mathrm{C} 5(11)], 43.2$ $\left(\mathrm{CH}_{2}, \mathrm{C} 8\right), 52.5\left(\mathrm{CH}_{2}, \mathrm{CH}_{2} \mathrm{C}_{6} \mathrm{H}_{5}\right), 67.9$ (C, C7), 127.0 ( $\left.\mathrm{CH}, \mathrm{Ar}-\mathrm{C}_{\text {meta }}\right)$, 128.0 [CH, C2(3)], 129.0 [CH, C1(4)], 129.2 (C, Ar-C $\left.\mathrm{C}_{\text {ipso }}\right), 129.7$ (CH, Ar- $\left.\mathrm{C}_{\text {para }}\right), 131.7$ ( $\left.\mathrm{CH}, \mathrm{Ar}-\mathrm{C}_{\text {ortho }}\right), 144.89$ (C), and 144.92 (C) (C4a and C11a). MS (EI), m/z (\%): $331\left(\mathrm{M}^{+}, 100\right), 316$ (33), 290 (18), 289 (77), 288 (12), 274 (12), 260 (10), 246 (11), 240 (10), 211 $\left[\left(\mathrm{C}_{16} \mathrm{H}_{19}\right)^{+}, 11\right], 198(22), 169(10), 161(10), 160(16), 155(30)$, 143 (18), 141 (18), 129 (18), 128 (18), 115 (13), 91 (61). Anal. Calcd. for $\mathrm{C}_{24} \mathrm{H}_{30} \mathrm{NCl} \cdot 0.3 \mathrm{H}_{2} \mathrm{O}$ (373.37): $\mathrm{C} 77.21, \mathrm{H}$ 8.26, N 3.75, $\mathrm{Cl} 9.50$. Found C 76.96, H 8.21, N 3.67, Cl 9.89.

\subsection{6. $N$-Methyl-6,7,8,9,10,11-hexahydro-9-methyl-5,7:9,11-dim ethano-5H-benzocyclononen-7-amine hydrochloride, $8 \cdot \mathbf{H C l}$}

A suspension of $\mathbf{7} \cdot \mathbf{H C l}$ (184 $\mathrm{mg}, 0.50 \mathrm{mmol}$ ) and $5 \% \mathrm{Pd} / \mathrm{C}$ ( $50 \%$ in water, $50 \mathrm{mg})$ in absolute EtOH $(25 \mathrm{~mL})$ was hydrogenated at $1 \mathrm{~atm}$ and $90^{\circ} \mathrm{C}$ for $24 \mathrm{~h}$. The suspension was filtered, the residue was washed with EtOH and to the combined organic filtrates an excess of $\mathrm{Et}_{2} \mathrm{O} \cdot \mathrm{HCl}$ was added. Evaporation of the solvents from the filtrate in vacuo followed by crystallization of the residue from methanol/ $\mathrm{Et}_{2} \mathrm{O}$ gave $\mathbf{8} \cdot \mathbf{H C l}$ ( $102.8 \mathrm{mg}, 74 \%$ yield) as a white solid, $\mathrm{mp}>225$ dec. IR 3419, 2910, 2846, 2692, 2133, 2094, 2061, 1867, 1447, 1367, 1215, 1172, 1126, 1072, 1007, 957, 773, 574, $509 \mathrm{~cm}^{-1} .{ }^{1} \mathrm{H}$ NMR $1.00\left(\mathrm{~s}, 3 \mathrm{H}, \mathrm{C} 9-\mathrm{CH}_{3}\right), 1.56$ [d, $\left.J=13.5 \mathrm{~Hz}, 2 \mathrm{H}, 10(13)-\mathrm{H}_{\mathrm{b}}\right], 1.70$ (s, $\left.2 \mathrm{H}, 8-\mathrm{H}_{2}\right), 1.73$ [dd, $J=13.5 \mathrm{~Hz}, J^{\prime}=6.0 \mathrm{~Hz}, 2 \mathrm{H}, 10(13)-\mathrm{H}_{\mathrm{a}}$ ], 1.90 [d, $J=12.5 \mathrm{~Hz}, 2 \mathrm{H}, 6(12)-\mathrm{H}_{\mathrm{b}}$ ], 2.07 [dd, $J=12.5 \mathrm{~Hz}, J^{\prime}=6.5 \mathrm{~Hz}, 2 \mathrm{H}$, 6(12)- $\mathrm{H}_{\mathrm{a}}$ ], $2.61\left(\mathrm{~s}, 3 \mathrm{H}, \mathrm{N}-\mathrm{CH}_{3}\right), 3.24[\mathrm{~m}, 2 \mathrm{H}, 5(11)-\mathrm{H}], 7.10(\mathrm{~s}, 4 \mathrm{H}$, Ar-H). ${ }^{13} \mathrm{C}$ NMR $25.6\left(\mathrm{CH}_{3}, \mathrm{CH}_{3}-\mathrm{N}\right), 32.3\left(\mathrm{CH}_{3}, \mathrm{C}_{-}-\mathrm{CH}_{3}\right), 34.9$ (C, $\left.\mathrm{C} 9\right)$, $36.8\left[\mathrm{CH}_{2}, \mathrm{C} 6(12)\right], 41.5[\mathrm{CH}, \mathrm{C} 5(11)], 41.7\left[\mathrm{CH}_{2}, \mathrm{C} 10(13)\right], 45.3$ $\left(\mathrm{CH}_{2}, \mathrm{C} 8\right), 60.3(\mathrm{C}, \mathrm{C} 7), 128.0[\mathrm{CH}, \mathrm{C} 2(3)], 129.2[\mathrm{CH}, \mathrm{C} 1(4)], 146.3$ [C, C4a(C11a)]. MS (EI), m/z (\%): $241\left(\mathrm{M}^{+}, 100\right), 226$ (35), 200 (12), 199 (72), 198 (12) 184 (40), 171 (14), 170 (47), 169 (13), 158 (14), 156 (11), 155 (30), 153 (11), 144 (11), 143 (12), 141 (23), 129 (22), 128 (28), 122 (21), 115 (27), 108 (29), 91 (10), 71 (28), 57 (10), 56 (15). HRMS-ESI $+m / z[M+H]^{+}$calcd for $\mathrm{C}_{17} \mathrm{H}_{23} \mathrm{~N}+\mathrm{H}$ : 242.1903 , found: 242.1902. Anal. Calcd. for $\mathrm{C}_{17} \mathrm{H}_{23} \mathrm{~N} \cdot 1.6 \mathrm{HCl}$ (299.71): C 68.13, H 8.27, N 4.67. Found C 68.11, H 8.20, N 4.27.

\subsection{7. $N$-Propargyl-6,7,8,9,10,11-hexahydro-9-methyl-5,7:9,11-di methano-5H-benzocyclononen-7-amine hydrochloride, $9 \cdot \mathbf{H C l}$, and $N, N$-dipropargyl-6,7,8,9,10,11-hexahydro-9-methyl-5,7:9, 11-dimethano-5H-benzocyclononen-7-amine hydrochloride, 10.HCl}

A suspension of $\mathbf{3} \cdot \mathbf{H C l}$ ( $400 \mathrm{mg}, 1.52 \mathrm{mmol}), \mathrm{K}_{2} \mathrm{CO}_{3}$ (246 mg, $1.78 \mathrm{mmol})$, propargyl bromide $(0.22 \mathrm{~mL}, 80 \%$ solution in toluene, $1.98 \mathrm{mmol})$ and $\mathrm{NaI}(21 \mathrm{mg}, 0.14 \mathrm{mmol})$ in acetonitrile $(15 \mathrm{~mL})$ was heated under reflux for $18 \mathrm{~h}$. After concentration to dryness in vacuo, the residue was taken in $\mathrm{CH}_{2} \mathrm{Cl}_{2}(20 \mathrm{~mL})$ and the solution was washed with water $(3 \times 10 \mathrm{~mL})$. The organic layer was dried with anhyd $\mathrm{Na}_{2} \mathrm{SO}_{4}$, filtered and concentrated in vacuo to give a residue which was subjected to column chromatography (hexane/ EtOAc mixtures) affording 10 (hexane/EtOAc 99/1, $220 \mathrm{mg}, 48 \%$ yield) and $\mathbf{9}$ (hexane/EtOAc $97 / 3,70 \mathrm{mg}, 17 \%$ yield). The hydrochlorides of 9 and 10 were obtained by adding an excess of $\mathrm{Et}_{2} \mathrm{O} \cdot \mathrm{HCl}$ to a solution of the corresponding amine in EtOAc, followed by filtration of the formed precipitate. The analytical samples were obtained by crystallization from methanol/Et ${ }_{2} \mathrm{O} . \mathbf{9} \cdot \mathbf{H C l}$ : $\mathrm{mp} 175-176{ }^{\circ} \mathrm{C}$ (metha$\left.\mathrm{nol} / \mathrm{Et}_{2} \mathrm{O}\right)$. IR 3487, 3221, 2908, 2446, 2366, 2125, 1628, 1451, 850, $761,548 \mathrm{~cm}^{-1}$. ${ }^{1} \mathrm{H}$ NMR $1.00\left(\mathrm{~s}, 3 \mathrm{H}, \mathrm{C} 9-\mathrm{CH}_{3}\right), 1.56$ [d, $J=13.5 \mathrm{~Hz}$, $2 \mathrm{H}, 10(13)-\mathrm{H}_{\mathrm{b}}$ ], $1.71\left(\mathrm{~s}, 2 \mathrm{H}, 8-\mathrm{H}_{2}\right), 1.73$ [ddd, $J=13.5 \mathrm{~Hz}, J^{\prime}=6.0 \mathrm{~Hz}$, $\left.J^{\prime}=2.0 \mathrm{~Hz}, 2 \mathrm{H}, 10(13)-\mathrm{H}_{\mathrm{a}}\right], 1.93\left[\mathrm{~d}, J=12.5 \mathrm{~Hz}, 2 \mathrm{H}, 6(12)-\mathrm{H}_{\mathrm{b}}\right], 2.08$ $\left[\mathrm{dm}, J=12.5 \mathrm{~Hz}, 2 \mathrm{H}, 6(12)-\mathrm{H}_{\mathrm{a}}\right.$ ], $3.20\left(\mathrm{t}, J=2.5 \mathrm{~Hz}, 1 \mathrm{H}, \mathrm{CH}_{2} \mathrm{C} \equiv \mathrm{CH}\right)$, $3.23\left[\mathrm{tm}, J^{\prime}=6.0 \mathrm{~Hz}, 2 \mathrm{H}, 5(11)-\mathrm{H}\right], 3.94\left(\mathrm{~d}, J=2.5 \mathrm{~Hz}, 2 \mathrm{H}, \mathrm{CH}_{2} \mathrm{C} \equiv \mathrm{CH}\right)$, 7.10 (s, 4H, Ar-H). ${ }^{13} \mathrm{C}$ NMR $30.5\left(\mathrm{CH}_{2}, \mathrm{CH}_{2} \mathrm{C} \equiv \mathrm{CH}\right), 32.3\left(\mathrm{CH}_{3}, \mathrm{C} 9-\right.$ $\left.\mathrm{CH}_{3}\right), 34.9$ (C, $\left.\mathrm{C} 9\right), 37.0\left[\mathrm{CH}_{2}, \mathrm{C} 6(12)\right], 41.5[\mathrm{CH}, \mathrm{C} 5(11)], 41.6\left[\mathrm{CH}_{2}\right.$, $\mathrm{C} 10(13)], 45.3\left(\mathrm{CH}_{2}, \mathrm{C} 8\right), 61.7(\mathrm{C}, \mathrm{C} 7), 75.5\left(\mathrm{CH}, \mathrm{CH}_{2} \mathrm{C} \equiv \mathrm{CH}\right), 78.7$ (C, $\left.\mathrm{CH}_{2} \mathrm{C} \equiv \mathrm{CH}\right), 128.0[\mathrm{CH}, \mathrm{C} 2(3)], 129.2[\mathrm{CH}, \mathrm{C} 1(4)], 146.2[\mathrm{C}$, C4a(C11a)]. HRMS-ESI+ $m / z \quad[M+\mathrm{H}]^{+}$calcd for $\mathrm{C}_{19} \mathrm{H}_{23} \mathrm{~N}+\mathrm{H}$ : 266.1903, found: 266.1898. Anal. Calcd for $\mathrm{C}_{19} \mathrm{H}_{23} \mathrm{~N} \cdot 1.5 \mathrm{HCl}$ (320.09): C 71.30, H 7.71, N 4.38. Found C 71.56, H 7.73, N 4.15. 10.HCl: $\mathrm{mp} 199-200^{\circ} \mathrm{C}$ (methanol/Et ${ }_{2} \mathrm{O}$ ). IR 3305, 3239, 3194, 2951, 2907, 2346, 2118, 1493, 1474, 1455, 1435, 1380, 1355 , 1308, 1212, 1166, 1039, 1007, 959, 884, 845, 755, 691, 639, $546 \mathrm{~cm}^{-1} .{ }^{1} \mathrm{H}$ NMR $1.03\left(\mathrm{~s}, 3 \mathrm{H}, \mathrm{C} 9-\mathrm{CH}_{3}\right), 1.54[\mathrm{~d}, J=13.5 \mathrm{~Hz}, 2 \mathrm{H}$, $10(13)-\mathrm{H}_{\mathrm{b}}$ ], 1.73 [dd, $J=13.5 \mathrm{~Hz}, J^{\prime}=6.0 \mathrm{~Hz}, 2 \mathrm{H}, 10(13)-\mathrm{H}_{\mathrm{a}}$ ], 1.90 (s, 
$\left.2 \mathrm{H}, 8-\mathrm{H}_{2}\right), 2.13$ [d, $J=12.0 \mathrm{~Hz}, 2 \mathrm{H}, 6(12)-\mathrm{H}_{\mathrm{b}}$ ], 2.30 [dd, $J=12.0 \mathrm{~Hz}$, $J^{\prime}=6.5 \mathrm{~Hz}, 2 \mathrm{H}, 6(12)-\mathrm{H}_{\mathrm{a}}$ ], 3.27 [t, J'= $\left.6.0 \mathrm{~Hz}, 2 \mathrm{H}, 5(11)-\mathrm{H}\right], 4.32(\mathrm{br}$ $\left.\mathrm{s}, 4 \mathrm{H}, \mathrm{CH}_{2} \mathrm{C} \equiv \mathrm{CH}\right), 7.10(\mathrm{~s}, 4 \mathrm{H}, \mathrm{Ar}-\mathrm{H})$. The signal corresponding to the terminal $\equiv \mathrm{CH}$ was not observed. ${ }^{13} \mathrm{C} \mathrm{NMR} 32.5\left(\mathrm{CH}_{3}, \mathrm{C} 9-\mathrm{CH}_{3}\right)$, 35.9 (C, C9), $36.0\left[\mathrm{CH}_{2}, \mathrm{C} 6(12)\right], 38.4\left(\mathrm{CH}_{2}, \mathrm{CH}_{2} \mathrm{C} \equiv \mathrm{CH}\right), 41.4\left[\mathrm{CH}_{2}\right.$, C10(13)], 41.9 [CH, C5(11)], $45.0\left(\mathrm{CH}_{2}, \mathrm{C} 8\right), 71.7$ (C, C7), $74.8(\mathrm{CH}$, $\left.\mathrm{CH}_{2} \mathrm{C} \equiv \mathrm{CH}\right), 80.9\left(\mathrm{C}, \mathrm{CH}_{2} \mathrm{C} \equiv \mathrm{CH}\right), 128.1[\mathrm{CH}, \mathrm{C} 2(3)], 129.2[\mathrm{CH}$, C1(4)], 146.3 [C, C4a(C11a)]. MS (EI), m/z (\%): $303\left(\mathrm{M}^{+}, 87\right), 302$ (35), 288 (28), 260 (38), 246 (19), 232 (10), 218 (12), 211 (25), 206 (27), 169 (21), 167 (11), 165 (11), 156 (15), 155 (77), 153 (15), 144 (11), 143 (42), 142 (13), 141 (40), 133 (63), 132 (100), 130 (18), 129 (46), 128 (35), 127 (11), 118 (11), 117 (16), 115 (30), 91 (15). Anal. Calcd for $\mathrm{C}_{22} \mathrm{H}_{26} \mathrm{ClN}$ (339.91): C 77.74, H 7.71, N 4.12, $\mathrm{Cl}$ 10.43. Found C 77.63, H 7.61, N 3.94, Cl 10.06.

\subsection{8. $N, N$-Dimethyl-6,7,8,9,10,11-hexahydro-9-methyl-5,7:9,11- dimethano-5H-benzocyclononen-7-amine hydrochloride, 11. HCl}

To a solution of $\mathbf{3} \cdot \mathbf{H C l}(300 \mathrm{mg}, 1.14 \mathrm{mmol})$ in $\mathrm{MeOH}(10 \mathrm{~mL})$, $\mathrm{NaBH}_{3} \mathrm{CN}$ (205 mg, $\left.3.27 \mathrm{mmol}\right), \mathrm{AcOH}(0.3 \mathrm{~mL})$ and formaldehyde $(0.26 \mathrm{~mL}, 37 \%$ wt. in water solution, $3.48 \mathrm{mmol})$ were added and the mixture was stirred at room temperature for $8 \mathrm{~h}$. An additional portion of $\mathrm{NaBH}_{3} \mathrm{CN}(205 \mathrm{mg}, 3.27 \mathrm{mmol})$ and formaldehyde $(0.26 \mathrm{~mL}, 37 \% \mathrm{wt}$. in water solution, $3.48 \mathrm{mmol})$ were added, the mixture was stirred at room temperature for $18 \mathrm{~h}$ and then it was concentrated in vacuo to dryness. Water $(20 \mathrm{~mL})$ was added to the residue, the suspension was basified with $1 \mathrm{~N} \mathrm{NaOH}$ $(10 \mathrm{~mL})$ and was extracted with EtOAc $(4 \times 15 \mathrm{~mL})$. The combined organic extracts were washed with brine $(2 \times 10 \mathrm{~mL})$, dried with anhyd $\mathrm{Na}_{2} \mathrm{SO}_{4}$, filtered and concentrated in vacuo to give $\mathbf{1 1}$ as a yellow oil. Its hydrochloride was obtained by adding an excess of $\mathrm{Et}_{2} \mathrm{O} \cdot \mathrm{HCl}$ to a solution of the amine in EtOAc, followed by filtration of the white solid precipitate ( $249 \mathrm{mg}, 75 \%$ yield), $\mathrm{mp} 226-227^{\circ} \mathrm{C}$. IR 3468, 3411, 3244, 3063, 3022, 2945, 2917, 2892, 2865, 2846, 2670, 2462, 2071, 1635, 1492, 1458, 1449, 1409, 1369, 1309, $1215,1176,1155,1125,1096,1051,980,903,756,584 \mathrm{~cm}^{-1} .{ }^{1} \mathrm{H}$ $\operatorname{NMR}\left(\mathrm{CDCl}_{3}\right) 0.97\left(\mathrm{~s}, 3 \mathrm{H}, \mathrm{C} 9-\mathrm{CH}_{3}\right), 1.56$ [d, $J=13.5 \mathrm{~Hz}, 2 \mathrm{H}, 10(13)-$ $\mathrm{H}_{\mathrm{b}}$ ], 1.66 [dd, $J=13.5 \mathrm{~Hz}, J^{\prime}=6.0 \mathrm{~Hz}, 2 \mathrm{H}, 10(13)-\mathrm{H}_{\mathrm{a}}$ ], $1.88(\mathrm{~s}, 2 \mathrm{H}$, $\left.8-\mathrm{H}_{2}\right), 1.92\left[\mathrm{~d}, J=12.0 \mathrm{~Hz}, 2 \mathrm{H}, 6(12)-\mathrm{H}_{\mathrm{b}}\right], 2.17$ (br s, $\left.1 \mathrm{H}, \mathrm{NH}\right)$, $2.25\left[\mathrm{dd}, J=12.0 \mathrm{~Hz}, J^{\prime}=6.0 \mathrm{~Hz}, 2 \mathrm{H}, 6(12)-\mathrm{H}_{\mathrm{a}}\right.$ ], $2.69\left(\mathrm{~s}, 6 \mathrm{H}, \mathrm{N}-\mathrm{CH}_{3}\right)$, $3.20[\mathrm{t}, J=6.0 \mathrm{~Hz}, 2 \mathrm{H}, 5(11)-\mathrm{H}], 7.04[\mathrm{~m}, 2 \mathrm{H}, 1(4)-\mathrm{Ar}-\mathrm{H}], 7.10[\mathrm{~m}$, $2 \mathrm{H}, 2(3)-\mathrm{Ar}-\mathrm{H}] .{ }^{13} \mathrm{C} \mathrm{NMR}\left(\mathrm{CDCl}_{3}\right) 31.8\left(\mathrm{CH}_{3}, \mathrm{C} 9-\mathrm{CH}_{3}\right), 33.2\left[\mathrm{CH}_{2}\right.$, C6(12)], 34.3 (C, C9), $36.4\left(\mathrm{CH}_{3}, \mathrm{CH}_{3}-\mathrm{N}\right), 40.0\left[\mathrm{CH}_{2}, \mathrm{C} 10(13)\right], 40.1$ [CH, C5(11)], $43.6\left(\mathrm{CH}_{2}, \mathrm{C} 8\right), 65.3$ (C, C7), 127.1 [CH, C2(3)], 128.2 [CH, C1(4)], 144.8 [C, C4a(C11a)]. MS (EI), m/z (\%): $255\left(\mathrm{M}^{+}, 100\right)$, 240 (39), 214 (15), 213 (88), 212 (17), 198 (29), 185 (11), 184 (22), 170 (13), 169 (10), 155 (35), 153 (10), 143 (12), 141 (22), 136 (12), 129 (17), 128 (23), 122 (22), 115 (20), 85 (24). Anal. Calcd. for $\mathrm{C}_{18} \mathrm{H}_{26} \mathrm{NCl} \cdot 1.3 \mathrm{H}_{2} \mathrm{O}$ (315.28): C 68.57, $\mathrm{H} \mathrm{9.14,} \mathrm{N} \mathrm{4.44,} \mathrm{Cl}$ 11.24. Found C 68.29, $\mathrm{H} 8.84, \mathrm{~N} 4.52, \mathrm{Cl} 11.65$.

\subsection{9. $N$-(6,7,8,9,10,11-hexahydro-9-methyl-5,7:9,11-dimethano -5H-benzocyclononen-7-yl)piperidine hydrochloride, $12 \cdot \mathbf{H C l}$}

To a solution of $\mathbf{3} \cdot \mathbf{H C l}(288 \mathrm{mg}, 1.09 \mathrm{mmol})$ in DMF (4.0 mL), anhyd $\mathrm{Et}_{3} \mathrm{~N}(0.45 \mathrm{~mL}, 3.27 \mathrm{mmol})$ was added and the suspension was stirred at room temperature for 2 h. 1,5-Dibromopentane $(0.18 \mathrm{~mL}$, $1.3 \mathrm{mmol}$ ) was added and the mixture was heated at $60^{\circ} \mathrm{C}$ for $26 \mathrm{~h}$. To the cold mixture, water $(15 \mathrm{~mL})$ and $2 \mathrm{~N} \mathrm{NaOH}(10 \mathrm{~mL})$ were added and the solution was extracted with EtOAc $(6 \times 15 \mathrm{~mL})$. The combined organic extracts were washed with water $(3 \times 15 \mathrm{~mL})$, dried with anhyd $\mathrm{Na}_{2} \mathrm{SO}_{4}$ and filtered. Excess of $\mathrm{Et}_{2} \mathrm{O} \cdot \mathrm{HCl}$ was added and the solution was concentrated in vacuo to dryness to give $12 \cdot \mathrm{HCl}$ (125 mg, 35\% yield). The analytical sample of $12 \cdot \mathrm{HCl}$ was obtained by crystallization from methanol/Et ${ }_{2} \mathrm{O}, \mathrm{mp} 280^{\circ} \mathrm{C}$ (sub). IR 3427, 3023 , 2951, 2924, 2900, 2858, 2661, 2530, 2014, 1941, 1455, 1374, 1297, 1218, 1122, 1094, 973, 752, $551 \mathrm{~cm}^{-1} .{ }^{1} \mathrm{H}$ NMR $1.02(\mathrm{~s}, 3 \mathrm{H}$,
C9- $\mathrm{CH}_{3}$ ), 1.52 (br s, $1 \mathrm{H}$, piperidine $4-\mathrm{H}_{a x}$ ), $1.55[\mathrm{~d}, J=13.5 \mathrm{~Hz}, 2 \mathrm{H}$, $10(13)-\mathrm{H}_{\mathrm{b}}$ ], 1.73 [dd, $J=12.0 \mathrm{~Hz}, J^{\prime}=6.5 \mathrm{~Hz}, 2 \mathrm{H}, 10(13)-\mathrm{H}_{\mathrm{a}}$ ], $1.83(\mathrm{~s}$, $\left.2 \mathrm{H}, 8-\mathrm{H}_{2}\right), 1.83-1.98$ [complex signal, $5 \mathrm{H}$, piperidine $4-\mathrm{H}_{\mathrm{eq}}, 3(5)-$ $\mathrm{H}_{\mathrm{ax}}$ and $3(5)-\mathrm{H}_{\mathrm{eq}}$ ], 2.04 [d, $J=12.5 \mathrm{~Hz}, 2 \mathrm{H}, 6(12)-\mathrm{H}_{\mathrm{b}}$ ], 2.18 [dd, $J=12.5 \mathrm{~Hz}, J^{\prime}=6.5 \mathrm{~Hz}, 2 \mathrm{H}, 6(12)-\mathrm{H}_{\mathrm{a}}$ ] $2.92[\mathrm{br} \mathrm{s}, 2 \mathrm{H}$, piperidine 2(6) $-\mathrm{H}_{\mathrm{ax}}$ ] 3.27 [tm, J' $\left.=6.5 \mathrm{~Hz}, 2 \mathrm{H}, 5(11)-\mathrm{H}\right], 3.68$ [br s, $2 \mathrm{H}$, piperidine 2(6)- $\left.\mathrm{H}_{\mathrm{eq}}\right], 7.10(\mathrm{~s}, 4 \mathrm{H}, \mathrm{Ar}-\mathrm{H}) .{ }^{13} \mathrm{C}$ NMR $23.2\left(\mathrm{CH}_{2}\right.$, piperidine $\left.\mathrm{C} 4\right), 25.0$ $\left[\mathrm{CH}_{2}\right.$, piperidine $\left.\mathrm{C} 3(5)\right], 32.5\left(\mathrm{CH}_{3}, \mathrm{C} 9-\mathrm{CH}_{3}\right), 34.9\left[\mathrm{CH}_{2}, \mathrm{C} 6(12)\right], 35.6$ (C, C9), $41.5\left[\mathrm{CH}_{2}, \mathrm{C} 10(13)\right], 41.8[\mathrm{CH}, \mathrm{C} 5(11)], 44.3\left(\mathrm{CH}_{2}, \mathrm{C} 8\right), 47.7$ $\left[\mathrm{CH}_{2}\right.$, piperidine $\left.\mathrm{C} 2(6)\right], 68.8(\mathrm{C}, \mathrm{C} 7), 128.0[\mathrm{CH}, \mathrm{C} 2(3)], 129.2[\mathrm{CH}$, C1(4)], 146.4 [C, C4a(C11a)]. Anal. Calcd for. $\mathrm{C}_{21} \mathrm{H}_{30} \mathrm{NCl} \cdot 0.5 \mathrm{H}_{2} \mathrm{O}$ (340.93): C 73.98, H 9.16, N 4.11. Found C 73.79, H 8.93, N 3.91.

\subsection{NMDA receptor antagonist activity}

The functional assay of antagonist activity at NMDA receptors was performed using primary cultures of cerebellar granule neurons, that were prepared according to established protocols. ${ }^{12}$ Cells were grown on $10 \mathrm{~mm}$ poly-L-lysine coated glass cover slips, and used for the experiments after 7-14 days in vitro. Cells were loaded with $6 \mu \mathrm{M}$ Fura-2 AM (Invitrogen-Molecular Probes) for $45 \mathrm{~min}$. Afterwards, the coverslip was mounted on a quartz cuvette containing a Locke-Hepes buffer using a special holder. Measurements were performed using a PerkinElmer LS-50B fluorometer equipped with a fast-filter accessory, under mild agitation and at $37^{\circ} \mathrm{C}$. Analysis from each sample was recorded real-time during $1200 \mathrm{~s}$. After stimulation with NMDA or glutamate $(100 \mu \mathrm{M}$, in the presence of $10 \mu \mathrm{M}$ glycine), increasing cumulative concentrations of the compound to be tested were added. The percentages of inhibition at every tested concentration were analyzed using a non-linear regression curve fitting (variable slope) by using the software GraphPad Prism 4.0.

\subsection{Antiviral evaluation}

The antiviral activity of the compounds was determined in established cell culture assays using a selection of DNA and RNA viruses, including three subtypes of influenza virus [A/Puerto Rico/8/34 (H1N1); A/Hong Kong/7/87 (H3N2) and B/Hong Kong/ $5 / 72] .{ }^{16}$ The compounds' inhibitory effect on virus replication as well as their cytotoxicity were monitored by microscopical examination, and confirmed by the colorimetric MTS cell viability assay.

\subsection{Plasmid, mRNA synthesis, and microinjection of oocytes. Two-electrode voltage clamp analysis}

The cDNA encoding the influenza A/Udorn/72 (A/M2) was inserted into pGEM3 vector for the expression on oocyte plasma membrane. A/M2 S31N and A/M2 V27A mutants were generated by QuikChange site-directed mutagenesis kit (Agilent Technologies). The synthesis of mRNA and microinjection of oocytes have been described previously. ${ }^{17}$

Macroscopic membrane current was recorded $48-72 \mathrm{~h}$ after injection as described previously. ${ }^{18}$ The tested compounds were applied at $\mathrm{pH} 5.5$ at various concentrations when the inward current reaches maximum. The compounds were applied for $2 \mathrm{~min}$, and residual membrane current was compared with the membrane current before the application of compounds. Membrane currents were analyzed with pCLAMP 10.0 software package (Axon Instruments, Sunnyvale, CA).

\section{5. $T$. brucei culturing and drug testing}

Cultures of bloodstream form T. brucei (strain 427) were maintained at $37^{\circ} \mathrm{C}$ in modified Iscove's medium (pH 7.4)..$^{19}$ Trypanocidal activity was assessed by growing parasites for $48 \mathrm{~h}$ in the 
presence of various drug concentrations and determining the levels which inhibited growth by $50 \%\left(\mathrm{IC}_{50}\right)$ and $90 \%\left(\mathrm{IC}_{90}\right)$. In the case of untreated cultures (volume $4 \mathrm{~mL}$ ), cell densities increased from $0.25 \times 10^{5}$ to $1 \times 10^{6}$ cells $\mathrm{mL}^{-1}$ over this period. Experiments were performed in triplicate. Cell densities at each drug concentration were determined using a hemocytometer (Weber Scientific International Ltd), and drug sensitivity was expressed as a percentage of growth of control cells.

\section{Acknowledgments}

F.X.S. and S.V. gratefully acknowledge financial support from Ministerio de Educación y Ciencia (S.V.: Project CTQ2008-03768; F.X.S.: Project SAF 2006-13092-C02-01) and Comissionat per a Universitats $i$ Recerca (S.V.: Project 2005-SGR-00180, F.X.S.: Project 2009-SGR-853). J.M.K. was funded by the Wellcome Trust (Grant number 084175). E.T. and M.D.D. thank the Ministerio de Educación (FPU Program).

\section{References and notes}

1. (a) Danysz, W.; Parsons, C. G.; Kornhuber, J.; Schmidt, W. J.; Quack, G. Neurosci. Biobehav. Rev. 1997, 21, 455; (b) Parsons, C. G.; Danysz, W.; Quack, G. Neuropharmacology 1999, 38, 735; (c) Parsons, C. G.; Stöffler, A.; Danysz, W. Neuropharmacology 2007, 53, 699; (d) Gilling, K. E.; Jatzke, C.; Hechenberger, M.; Parsons, C. G. Neuropharmacology 2009, 56, 866.

2. Hay, A. J.; Wolstenholme, A. J.; Skehel, J. J.; Smith, M. H. EMBO J. 1985, 4, 3021; (b) Hay, A. J. Semin. Virol. 1992, 3, 21; (c) Pinto, L. H.; Holsinger, L. J.; Lamb, R. A. Cell 1992, 69, 517.

3. (a) Kelly, J. M.; Miles, M. A.; Skinner, A. C. Antimicrob. Agents Chemother. 1999, 43, 985; (b) Kelly, J. M.; Quack, G.; Miles, M. M. Antimicrob. Agents Chemother. 2001, 45,1360

4. Camps, P.; Duque, M. D.; Vázquez, S.; Naesens, L.; De Clercq, E.; Sureda, F. S.; López-Querol, M.; Camins, A.; Pallàs, M.; Prathalingam, S. R.; Kelly, J. M.; Romero, V.; Ivorra, D.; Cortés, D. Bioorg. Med. Chem. 2008, 16, 9925.

5. Duque, M. D.; Ma, C.; Torres, E.; Wang, J.; Naesens, L.; Juárez-Jiménez, J.; Camps, P.; Luque, F. J.; DeGrado, W. F.; Lamb, R. A.; Pinto, L. H.; Vázquez, S. J. Med. Chem. 2011, 54, 2646.

6. (a) Duque, M. D.; Camps, P.; Profire, L.; Montaner, S.; Vázquez, S.; Sureda, F. S.; Mallol, J.; López-Querol, M.; Naesens, L.; De Clercq, E.; Prathalingam, S. R.; Kelly, J. M. Bioorg. Med. Chem. 2009, 17, 3198; (b) Duque, M. D.; Camps, P.; Torres, E.; Valverde, E.; Sureda, F. S.; López-Querol, M.; Camins, A.; Prathalingam, S. R.; Kelly, J. M.; Vázquez, S. Bioorg. Med. Chem. 2010, 18, 46.

7. (a) Geldenhuys, W. J.; Malan, S. F.; Bloomquist, J. R.; Marchand, A. P.; van der Schyf, C. J. Med. Res. Rev. 2005, 25, 21; (b) Mdzinarishvili, A.; Geldenhuys, W. J.;
Abbruscato, T. J.; Bickel, U.; Klein, J.; van der Schyf, C. J. Neurosci. Lett. 2005, 383, 49; (c) Grobler, E.; Grobler, A.; van der Schyf, C. J.; Malan, S. F. Bioorg. Med. Chem. 2006, 14, 1176; (d) Kiewert, C.; Hartmann, J.; Stoll, J.; Thekkumkara, T. J.; Geldenhuys, W. J.; Klein, J. Neurochem. Res. 2006, 31, 395; (e) Geldenhuys, W. J.; Malan, S. F.; Bloomquist, J. R.; van der Schyf, C. J. Bioorg. Med. Chem. 2007, 15, 1525; (f) Hao, J.; Mdzinarishvili, A.; Abbruscato, T. J.; Klein, J.; Geldenhuys, W. J.; van der Schyf, C. J.; Bickel, U. Brain Res. 2008, 1196, 113.

8. (a) du Preez, J. L.; Lotter, A. P.; Guillory, J. K. Pharmazie 1996, 51, 223; (b) du Preez, J. L.; Lotter, A. P. Drug Dev. Ind. Pharm. 1996, 22, 1249.

9. (a) Bishop, R.; Landers, A. E. Aust. J. Chem. 1979, 32, 2675; (b) Amini; Bishop, R Aust. J. Chem. 1983, 36, 2465; (c) Amini; Bishop, R.; Burgess, G.; Craig, D. C. Dance, I. G.; Scudder, M. L. Aust. J. Chem. 1989, 42, 1919.

10. The Ritter reaction of diene $\mathbf{4}$ with acetonitrile was described in Ref. 90 However, in our hands, the hydrolysis of this acetamide with aq. $\mathrm{HCl}$ gave amine 3 in low yield. Only under very drastic basic conditions $(\mathrm{NaOH}$, diethyleneglycol at $210^{\circ} \mathrm{C}$ for $\left.24 \mathrm{~h}\right) 3$ was obtained in high yield (89\%).

11. Jirgensons, A.; Kauss, V.; Kalvinsh, I.; Gold, M. R. Synthesis 2000, 1709.

12. Canudas, A. M.; Pubill, D.; Sureda, F. X.; Verdaguer, E.; Camps, P.; MuñozTorrero, D.; Jiménez, A.; Camins, A.; Pallàs, M. Exp. Neurol. 2003, 180, 123.

13. (a) Papanastasiou, I.; Tsotinis, A.; Kolocouris, N.; Prathalingam, S. R.; Kelly, J. M. J. Med. Chem. 2008, 51, 1496; (b) Zoidis, G.; Tsotinis, A.; Kolocouris, N.; Kelly, J. M.; Prathalingam, S. R.; Naesens, L.; De Clercq, E. Org. Biomol. Chem. 2008, 6, 3177; (c) Papanastasiou, I.; Tsotinis, A.; Zoidis, G.; Kolocouris, N.; Prathalingam, S. R.; Kelly, J. M. ChemMedChem 2009, 4, 1059; (d) Zoidis, G.; Kolocouris, N.; Kelly, J. M.; Prathalingam, S. R.; Naesens, L.; De Clercq, E. Eur. J. Med. Chem. 2010, 45, 5022; (e) Fytas, C.; Zoidis, G.; Tzoutzas, N.; Taylor, M. C.; Fytas, G.; Kelly, J. M. J. Med. Chem. 2011, 54, 5250.

14. (a) Cady, S. D.; Schmidt-Rohr, K.; Wang, J.; Soto, C. S.; DeGrado, W. F. Nature 2010, 463, 689; (b) Acharya, R.; Carnevale, V.; Fiorin, G.; Levine, B. G.; Polishchuk, A. L.; Balannik, V.; Samish, I.; Lamb, R. A.; Pinto, L. H. Proc. Natl. Acad. Sci. U.S.A. 2010, 107, 15075; (c) Wang, J.; Qui, J. X.; Soto, C.; DeGrado, W. F. Curr. Opin. Struct. Biol. 2011, 21, 68.

15. (a) Deyde, V. M.; Xu, X.; Bright, R. A.; Shaw, M.; Smith, C. B.; Zhang, Y.; Shu, Y.; Gubareva, L. V.; Cox, N. J.; Klimov, A. I. J. Infect. Dis. 2007, 196, 249; (b) Furuse, Y.; Suzuki, A.; Kamigaki, T.; Oshitani, H. Virol. J. 2009, 6, 67; (c) Astrahan, P.; Arkin, I. T. Biochim. Biophys. Acta, Biomembr. 2011, 1808, 547; (d) Balannik, V.; Carnevale, V.; Fiorin, G.; Levine, B. G.; Lamb, R. A.; Klein, M. L.; DeGrado, W. F.; Pinto, L. H. Biochemistry 2010, 49, 696.

16. (a) Setaki, D.; Tataridis, D.; Stamatiou, G.; Kolocouris, A.; Foscolos, G. B.; Fytas, G.; Kolocouris, N.; Padalko, E.; Neyts, J.; De Clercq, E. Bioorg. Chem. 2006, 34, 248; (b) Naesens, L.; Vanderlinden, E.; Roth, E.; Jeko, J.; Andrei, G.; Snoeck, R.; Pannecouque, C.; Illyes, E.; Batta, G.; Herczegh, P.; Sztaricskai, F. Antiviral Res. 2009, 82, 89 .

17. Ma, C.; Soto, C. S.; Ohigashi, Y.; Taylor, A.; Bournas, V.; Glawe, B.; Udo, M. K. DeGrado, W. F.; Lamb, R. A.; Pinto, L. H. J. Biol. Chem. 2008, 283, 15921.

18. Balannik, V.; Wang, J.; Ohigashi, Y.; Jing, X.; Magavern, E.; Lamb, R. A.; DeGrado, W. F.; Pinto, L. H. Biochemistry 2009, 48, 11872.

19. Hirumi, H.; Hirumi, K. J. Parasitol. 1989, 75, 985. 